\title{
Influence of Rhizobia Inoculation on Biomass Gain and Tissue Nitrogen Content of Leucaena leucocephala Seedlings under Drought
}

\author{
Gabriela Pereyra ${ }^{1, *}$, Henrik Hartmann ${ }^{1}$, Beate Michalzik ${ }^{2}$, Waldemar Ziegler ${ }^{1}$ and \\ Susan Trumbore ${ }^{1}$
}

1 Max Planck Institute for Biogeochemistry, Hans-Knöll-str. 10, 07745 Jena, Germany; E-Mails: hhart@bgc-jena.mpg.de (H.H.); wziegler@bgc-jena.mpg.de (W.Z.); trumbore@bgc-jena.mpg.de (S.T.)

2 Institute of Geography, Faculty of Chemical and Earth Sciences, Friedrich-Schiller-Universität Jena, Löbdergraben 32, 07743 Jena, Germany; E-Mail: beate.michalzik@uni-jena.de

* Author to whom correspondence should be addressed; E-Mail: gpereyra@bgc-jena.mpg.de; Tel.: +49-3641-576176.

Academic Editors: Reynaldo Campos Santana and Eric J. Jokela

Received: 25 June 2015 / Accepted: 10 October 2015 / Published: 15 October 2015

\begin{abstract}
Anticipated increases in the frequency of heat waves and drought spells may have negative effects on the ability of leguminous trees to fix nitrogen $(\mathrm{N})$. In seedlings of Leucaena leucocephala inoculated with Mesorhizobium loti or Rhizobium tropici, we investigated how the developmental stage and a short drought influenced overall biomass and the accumulation of carbon and $\mathrm{N}$ in plant tissues. In early developmental stages, the number of nodules and nodule biomass were correlated with total plant biomass and $\delta^{15} \mathrm{~N}$, and nodules and roots contributed $33 \%-35 \%$ of the seedling total N. Seedlings associated with $R$. tropici fixed more $\mathrm{N}$ and exhibited higher overall biomass compared with $M$. loti seedlings. Four and a half months after inoculation (140 days after inoculation, DAI), a short (15-day) drought inhibited seedling growth and caused a decline in total plant $\mathrm{N}$, with the smallest decline in $R$. tropici seedlings. After 15 days of drought, i.e., 155 DAI, the nodules had accumulated proline, but the total amino acid concentration did not change. Our results indicate that N-fixation is independent of seedlings growth. In addition, $R$. tropici is a better choice than $M$. loti as a symbiont for Leucaena seedlings for forest restoration and agroforestry applications under increasingly drier conditions.
\end{abstract}


Keywords: symbiosis; nodulation; nitrogen fixation; Rhizobium tropici; Mesorhizobium loti; reforestation; ${ }^{15} \mathrm{~N}$ abundance; agroforestry

\section{Introduction}

Leguminous tree species play an important role in ecosystem productivity and diversity due to their association with nitrogen $(\mathrm{N})$-fixing diazotropic soil bacteria called rhizobia [1]. This symbiosis can increase net plant productivity [2] and mitigate land degradation through the use of fast-growing $\mathrm{N}$-fixing trees or shrub "pioneers" in restoration plantations [3]. However, anticipated changes in climate, such as more frequent drought and heat waves [4], may have the potential to negatively impact the usefulness of leguminous species or legume-symbiont partners for restoration purposes [5].

$\mathrm{N}$ fixation takes place mostly in root nodules that provide an environment where symbiotic bacteria convert atmospheric dinitrogen $\left(\mathrm{N}_{2}\right)$ into ammonia. Plants provide organic-acids as an energy source and in exchange are supplied with fixed $\mathrm{N}$ [6]. This symbiotic interaction is usually highly specific; each rhizobium species and/or strain interacts with only a specific group of legumes [7]. Such specificity can be expressed at early stages of the interaction, i.e., during bacterial infection and nodule development, or at later stages when N-fixation takes place [7]. However, some rhizobia species, such as Rhizobium sp. strain NGR234 and Mesorhizobium sp., are known to be less plant-specific and to interact with several legume species [7-9].

Variations in plant-rhizobia interactions can influence the successful establishment of legume trees during early developmental stages (i.e., seedlings) [10] and can influence the benefit accrued from the symbiosis. Such benefits are usually evaluated based on traits measured in the plant (e.g., total plant biomass, $\mathrm{N}$ content) [10], nodules (e.g., number of nodules, nodule biomass) [11,12] or nodule physiological parameters (e.g., apparent nitrogenase activity in relation to respiration) [12]. Nodule traits such as number of nodules [13] and nodule biomass [14] clearly depend on plant carbon (C), and are sensitive to environmental factors (i.e., drought stress) that can influence plant $C$ supply $[5,15]$.

Methods for estimating time-integrated rates of symbiotic $\mathrm{N}$ fixation in plant tissues rely on differences in the ${ }^{15} \mathrm{~N}$ content of biologically fixed $\mathrm{N}$ (with $\delta^{15} \mathrm{~N}$ values close to $0 \%$ ) compared with $\mathrm{N}$ taken up from the soil by plants (in tropical forests, $\delta^{15} \mathrm{~N}$ values are much greater than $0 \%$ ) [16]. $\delta^{15} \mathrm{~N}$ values can vary substantially between organs and tissues of a single plant [17]. For example, $\mathrm{N}$-fixing plants commonly exhibit ${ }^{15} \mathrm{~N}$ enrichment of nodules and a depletion of ${ }^{15} \mathrm{~N}$ in shoots [18], while averaged over the whole plant, $\delta^{15} \mathrm{~N}$ values are close to atmospheric $\mathrm{N}_{2}$ (i.e., close to $0 \%$ ) [18]. Tissue-specific $\delta^{15} \mathrm{~N}$ values have been related to the rate of nitrate reduction in roots and shoots [19], drought stress [20] and changes in the amount of $\mathrm{N}$-fixed relative to the $\mathrm{N}$ mass of the nodules [21].

Drought can reduce the amount of $\mathrm{C}$ available to rhizobia for fixing $\mathrm{N}$, which can lead to reductions in the total amount of $\mathrm{N}$ in plant tissues of legumes [5]. Stomatal closure associated with drought decreases the amount of new photosynthetic products. However, it can also reduce sinks for nonstructural carbohydrates (NSC) and reduce translocation of sugars to roots in drought-affected plants. Together, these can lead to the accumulation of NSC in above-ground tissues and depletion in roots, which in turn negatively affects $\mathrm{N}$ metabolism in the rhizobial symbiont [22-24]. Drought also 
induces changes in metabolite concentrations (i.e., amino acids) within the nodules, including increased concentrations of glutamine [25] and/or asparagine [26]. Such changes act as a signal for down-regulation of $\mathrm{N}$-fixation [22]. In this paper, we report the effect of drought on an important legume shrub species and explore the effect of rhizobium strain on plant development and drought response.

Leucaena leucocephala (L.) de Wit, hereafter Leucaena, often referred to as the "wonder tree", is a widely used woody legume species in the tropics and sub-tropics [27] and is an efficient means for sustaining the productivity of agroforestry systems [28]. For example, Leucaena improves soil fertility through biological N-fixation (up to $500 \mathrm{~kg} \mathrm{ha}^{-1}$ year $^{-1}$ of N) in tropical areas of southern Mexico [29] and subtropical areas of Australia [30]. Leucaena readily produces nodules in association with 8 different rhizobia strains isolated from 62 pan-tropical soils, including Rhizobium sp. [31] and Mesorhizobium loti [32]. It is clear that multipurpose legume tree species like Leucaena are important for ecosystem restoration and agroforestry. However, during critical developmental stages (i.e., seedling establishment), little is known about the effect of the rhizobia strain on the biomass gain and tissue $\mathrm{N}$ content, and how these are affected by drought stress.

In this study, our aims were to evaluate the influence of the identity of the rhizobium strain on: (i) the overall biomass and the total $\mathrm{C}$ and $\mathrm{N}$ content in plant tissues; and (ii) determine how these parameters changed during a short but intense drought. We hypothesized that during seedling establishment and drought, the identity of the rhizobium strain would affect the overall amount of $\mathrm{N}$ fixed by the plants. We also hypothesized that drought would limit plant growth and nodule energy supply to varying degrees in the different Leucaena-rhizobia associations, i.e., the degree of down-regulation of $\mathrm{N}$-fixation due to reduced $\mathrm{C}$ availability. To test these hypotheses, we inoculated Leucaena seedlings with two different rhizobial strains, M. loti or Rhizobium tropici, and measured plant and nodule biomass, as well as tissue $\mathrm{C}$ and $\mathrm{N}$ concentrations and ${ }^{15} \mathrm{~N}$ isotope enrichment during seedling development. We then compared how these traits were changed by a short drought period, and included measures of NSC and nodule amino acids to test whether limitations in energy supply affected plant growth, in particular, rhizosphere responses.

\section{Experimental Section}

\subsection{Biological Material and General Conditioning}

\subsubsection{Plant Growth Conditions}

Leucaena seeds were purchased from a commercial retailer (Sunshine-Seeds, Ahlen, Germany). We scarified seeds in $95 \%$ sulfuric acid for $10 \mathrm{~min}$ to ensure rapid and homogenous germination. After rinsing thoroughly with distilled water, the seeds were soaked in distilled water overnight. We placed the treated seeds in Petri dishes containing distilled water and covered them with parafilm $^{\mathrm{TM}}$ (Pechiney Plastic Packing Company, Chicago, IL, USA) to increase air humidity, and maintained them at $30^{\circ} \mathrm{C}$ for $48 \mathrm{~h}$. The pre-germinated seeds were individually transplanted into small pots $(0.3 \mathrm{~L})$ containing sterilized $\mathrm{C}$ - and $\mathrm{N}$-free vermiculite (oven dried at $100{ }^{\circ} \mathrm{C}$ for $8 \mathrm{~h}$ ) and were grown under controlled temperature at $25 / 20 \pm 1{ }^{\circ} \mathrm{C}$ (day/night) in the greenhouse at the Max Planck Institute for Biogeochemistry, Germany. Natural sunlight was supplemented during cloudy days with 
high-pressure sodium vapor lamps (400 W Gro-Lux ${ }^{\circledR}$, Osram Sylvania Ltd., Danvers, MA, USA) providing a minimum photosynthetic photon flux density (PPFD) of 400-500 $\mu \mathrm{mol} \mathrm{m} \mathrm{m}^{-2} \mathrm{~s}^{-1}$. All seedlings were irrigated every other day to substrate saturation (i.e., until drainage appeared in the trays). The pots were fertilized weekly with an $\mathrm{N}$-free nutrient solution with double the concentrations of the standard Hansen [33] nutrient solution, also to substrate saturation (approx. $50 \mathrm{~mL}$ per pot), forcing plants to rely exclusively on symbiotic $\mathrm{N}$-fixation as a source of $\mathrm{N}$. The nutrient solution contained: $\mathrm{MgSO}_{4} \cdot 7 \mathrm{H}_{2} \mathrm{O}(2.0 \mathrm{mM}), \mathrm{KH}_{2} \mathrm{PO}_{4}(0.5 \mathrm{mM}), \mathrm{K}_{2} \mathrm{HPO}_{4}(0.5 \mathrm{mM}), \mathrm{CaCl}_{2} \cdot 2 \mathrm{H}_{2} \mathrm{O}(2.0 \mathrm{mM})$, $\mathrm{K}_{2} \mathrm{SO} 4(1.0 \mathrm{mM})$, EDTA NaFe ${ }^{\mathrm{III}} \mathrm{O}(0.2 \mathrm{mM}), \mathrm{H}_{3} \mathrm{BO}_{3}(0.09 \mathrm{mM}), \mathrm{MnCl}_{2}(0.004 \mathrm{mM}), \mathrm{ZnCl}_{2}(0.0008$ $\mathrm{mM}), \mathrm{CuCl}_{2} \cdot 2 \mathrm{H}_{2} \mathrm{O}(0.0003 \mathrm{mM}), \mathrm{Na}_{2} \mathrm{MoO}_{4} \cdot 2 \mathrm{H}_{2} \mathrm{O}(0.0001 \mathrm{mM})$, and $\mathrm{CoCl}_{2}(0.00002 \mathrm{mM})$. Growth conditions were maintained throughout the entire experiment until the interruption of irrigation/fertilization during the drought pulse (see below).

\subsubsection{Bacterial Material}

Strains of Mesorhizobium loti [32] (Strain type: DSM No. 2627, Strain designation: NZP 2037) and Rhizobium tropici [34] (Strain type: DSM No. 11418, ATCC 49672, CIAT 899. Strain designation: HAMBI 1163) were used for the inoculation of Leucaena seedlings. Both strains were purchased at the Leibniz Institute DSMZ (German Collection of Microorganisms and Cell Cultures, Braunschweig, Germany). The bacterial strains were cultivated on a YEM (yeast extract mannitol) medium and the culture was incubated at $30^{\circ} \mathrm{C}\left( \pm 1.0^{\circ} \mathrm{C}\right)$ for four days.

\subsection{Experimental Design}

\subsubsection{Experiment 1: Growth and Early Development}

The first experiment assessed the growth and stoichiometric responses of Leucaena to different rhizobia strains (Leucaena $+M$. loti, Leucaena $+R$. tropici) during early seedling development. We planted 80 pots with germinated Leucaena seeds. After twenty days of growth, 35 seedlings were inoculated with a pure liquid culture of $M$. loti and another 35 were inoculated with $R$. tropici. This delay of 20 days was chosen to ensure homogenous seed germination prior to inoculation, and to avoid low inoculation success observed for L. leucocephala when immediate inoculation using seed coating was used [35]. Furthermore, we carried out inoculation pre-tests that showed liquid (1 mL) inoculation once seeds had germinated (i.e., seedlings one to two weeks old) yielded the best results in terms of the production of nodules over the subsequent weeks. Both bacterial cultures were applied to the surface of the soil using a liquid solution ( $1 \mathrm{~mL}$ of liquid inoculum, in the late-exponential growth phase for the culture) and randomly divided into subgroups according to their treatment. Ten pots received no bacterial strain inoculum and were used as non-fixing control plants (i.e., uninoculated plants).

Harvest days (i.e., 60 and 140 days after inoculation, DAI) were chosen based on preliminary greenhouse experiments with inoculated woody legumes. These experiments demonstrated that nodulation using liquid inoculum was achieved by 60 DAI [36]. In addition, other greenhouse and garden experiments studying the effectivity of rhizobia for nodulation found early $\mathrm{N}$-fixation and biomass accumulation in harvested Leucaena seedlings between 120 and 180 days after inoculation $[11,35,37,38]$. We harvested at 60 DAI assuming nodulation by this point (i.e., symbiosis 
was established), and then harvested half of the seedlings at 140 DAI when tissue lignification was visible, assuming that nodules were active and fixing $\mathrm{N}_{2}$ (Figure 1). Control seedlings (i.e., uninoculated) died approximately ten days after the first harvest (i.e., at $70 \mathrm{DAI}$ ) and no data were obtained for control plants at 140 DAI. Active N-fixation was identified via visual assessment of the harvested nodules based on their red/pink coloration. We retained 60 pots for the subsequent short drought experiment (Experiment 2).

\subsubsection{Experiment 2: Short Drought Pulse}

For experiment 2 (short drought), we used a subgroup of plants from experiment 1 (60 pots) (Figure 1). These plants were irrigated every other day until drainage appeared in the trays, and were fertilized weekly until 140 DAI when the short drought pulse started. In droughted plants, both irrigation and fertilization were completely discontinued. Control (i.e., irrigated) plants were irrigated (every other day) and fertilized (weekly) throughout the drought experiment with the nutrient solution and both groups (control and drought) were harvested at the end of the 15-day drought period (155 DAI). Seedlings were harvested at 0 (140 DAI) and 15 days after drought initiation (155 DAI), at the end of the experiment ( $n=6$ per treatment for each time point).

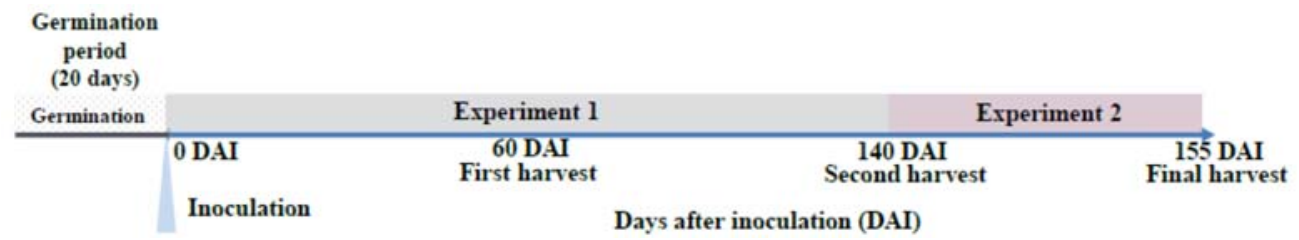

Figure 1. Schematic representation of the experimental time line. Experiment 2 was based on a subsample of plants from experiment 1 . The drought pulse lasted 15 days and plants were harvested for analysis at the start and end of this period.

\subsection{Sample Processing and Analysis}

\subsubsection{Sample Processing}

Harvested plants ( $n=6$ for each sampling point) were separated into leaves, branches/stems, roots, and nodules. Tissues from half of the harvested plants $(n=3)$ were oven-dried to constant weight at $70{ }^{\circ} \mathrm{C}$; their dry weight was recorded, and the material was stored for subsequent elemental and isotope analysis. Tissues of the other half $(n=3)$ of the plants harvested in the drought experiment were immediately frozen in liquid nitrogen and stored at $-80{ }^{\circ} \mathrm{C}$ for NSC analyses.

\subsubsection{Nitrogen Concentration and Isotopic Analysis}

Subsamples (5-20 mg DW) of oven-dried material were ground in a ball mill (Retsch MM200, Haan, Germany) to a fine powder, and then measured using an elemental analyzer (VarioMax Elementar Analysensysteme GmgH, Hanau, Germany). 
The total amount of $\mathrm{N}$ derived from biological fixation was calculated using the $\mathrm{N}$ balance method [39], where plants were grown in N-free media (i.e., vermiculite substrate) and the only source of $\mathrm{N}$ for growth, apart from seed- and inoculum-N, was $\mathrm{N}_{2}$ fixation. This was calculated as:

$$
\text { Total Plant } \mathrm{N}_{\text {fixed }}(\mathrm{g})=\mathrm{N}_{\text {(Leaves+Branches+Roots) }}(\mathrm{g})-\mathrm{N}_{\text {(in sown seed }+ \text { in inoculant) }}(\mathrm{g})
$$

For a given plant tissue, the amount of $\mathrm{N}$ was calculated from the amount of dry biomass and its measured $\mathrm{N}$ concentration:

$$
\text { Tissue } \mathrm{N}(\mathrm{g})=\left(\mathrm{N}_{\text {tissue }} \text { concentration }\left(\mathrm{mg} \mathrm{g}^{-1} \mathrm{DW}\right) \times \text { sample DW }(\mathrm{g})\right) / 1000
$$

The isotopic analysis of ${ }^{15} \mathrm{~N}$ abundance was conducted on a subsample of each tissue (c. $1 \mathrm{mg} \mathrm{DW}$ ) that was analyzed for $\delta^{15} \mathrm{~N}$ (expressed relative to atmospheric $\mathrm{N}_{2}$ ) at the Stable Isotope Laboratory of the Max Planck Institute for Biogeochemistry, using a Delta + XL Isotope Ratio Mass Spectrometry (IRMS, ThermoFinnigan, Bremen, Germany).

\subsubsection{Water Status}

In the drought experiment, the substrate water content (SWC) was defined as the percentage of the maximum mass of water retained by the substrate (i.e., field water capacity). SWC was estimated by weighing the pots between 07.00 and $08.00 \mathrm{~h}$ on days 0 and 15 following the day irrigation was stopped. SWC was estimated from the difference in the fresh weight (FW) and dry weight (DW) of the substrate contained in the pots measured after each harvest $(n=6$ per treatment):

$$
\mathrm{SWC}(\%)=100 \times\left(\mathrm{FW}-\mathrm{DW} / \mathrm{FW}_{\max }\right)
$$

\subsubsection{NSC and Amino Acid Concentrations}

Total NSC concentrations were estimated from the sum of the measurements of three major sugars within each tissue: glucose, fructose, and sucrose. Shock-frozen samples ( $n=3$ for each tissue type) of leaves, roots and nodules were vacuum freeze-dried for $96 \mathrm{~h}$ and milled (Retsch MM200, Haan, Germany) to a fine powder. After grinding, 5 to $30 \mathrm{mg}$ of the sample was added to $1 \mathrm{~mL}$ of distilled water. The mixture was vortexed and incubated for $10 \mathrm{~min}$ at $65{ }^{\circ} \mathrm{C}$ in a thermomixer and then centrifuged for $6 \mathrm{~min}$ at $12,000 \mathrm{~g}$. The supernatant was removed with a pipette, stored on ice and the water extraction procedure was repeated twice and the three extracts were combined. Sugars in the extract were measured using high/pressure liquid chromatography with pulse amperometric detection (HPLC-PAD) on a Dionex ICS 3000 ion chromatography system equipped with an autosampler [40]. Due to a freezer failure, the NSC in the leaf and root samples of the drought-control (irrigated) M. loti seedlings could not be measured.

An aliquot of the nodule sugar extracts was pipetted into tin cups and assayed with a Finnigan MAT DeltaPlus XL EA-IRMS (ThermoFinnigan GmbH, Bremen, Germany), coupled to an autosampler. Amino acid concentrations were quantified in the same extracts prepared for nodule NSC analyses, and were diluted at a ratio of 1:10 (v:v) in water. Amino acid measurements of the diluted extracts were performed at the Max Planck Institute for Chemical Ecology in Jena using liquid chromatography (LC-MS/MS) as described in Docimo, et al. [41], coupled to an API 5000 tandem mass spectrometer (Applied Biosystem, Darmstadt, Germany). All samples were spiked with ${ }^{13} \mathrm{C}$ - and ${ }^{15} \mathrm{~N}$-labeled 
amino acids (algal amino acids ${ }^{13} \mathrm{C},{ }^{15} \mathrm{~N}$, Isotec, Miamisburg, $\mathrm{OH}, \mathrm{USA}$ ) at a concentration of $10 \mu \mathrm{g}$ of the mix per $\mathrm{mL}$ solution. The concentration of individually labeled amino acids in the mix was determined by HPLC-fluorescence detection analysis after pre-column derivatization with ortho-phthaldialdehyde-mercaptoethanol using external standard curves made from standard mixtures (amino acid standard mix, Fluka plus Glutamine, Asparagine and Tryptophan, also Fluka). Individual amino acids in the sample were quantified by the respective ${ }^{13} \mathrm{C}$ - and ${ }^{15} \mathrm{~N}$-labeled amino acid internal standard, except for tryptophan and asparagine: tryptophan was quantified using ${ }^{13} \mathrm{C}$-, ${ }^{15} \mathrm{~N}$-Phenylalanine applying a response factor of 0.42 . Asparagine was quantified using ${ }^{13} \mathrm{C}$-, ${ }^{15} \mathrm{~N}$-Asparagine applying a response factor of 1.0 .

\subsection{Statistical Analysis}

Mean $( \pm \mathrm{SE})$ values of the measured parameters were tested for differences between strains and across harvest days by two-way ANOVA (strain and harvest days as factors for experiment 1 and experiment 2) using Type I sum of squares using R (v 3.1.0., R Foundation for Statistical Computing, 2012) [42] and the package Agricolae, version 1.1-8 [43]. When ANOVA indicated a significant overall treatment effect, a multiple comparison test was carried out (post hoc Least Significant Difference test) to compare parameter means across harvest days within rhizobia strains. To determine whether whole plant ${ }^{15} \mathrm{~N}$ discrimination was different from atmospheric $\mathrm{N}_{2}(0 \%)$, a $t$-test was performed across harvest days within strains.

\section{Results}

\subsection{Rhizobium Strain Effects on Seedling Carbon and Nitrogen Content}

At 60 DAI, the symbiosis of Leucaena with both inoculated rhizobia strains was clearly established, and had substantial effects. Uninoculated plants were shorter and had on average less biomass than inoculated plants. The leaf tissues of uninoculated plants had half the $\mathrm{N}$ concentration found in the leaves of inoculated seedlings (Table 1). Approximately ten days after the harvest (i.e., at $70 \mathrm{DAI}$ ), the uninoculated seedlings died, and no data were obtained for the control plants at 140 DAI.

At this early stage of development, the differences observed between plants infected with different rhizobia were mostly belowground. Fewer nodules were produced by $R$. tropici plants, but these had a similar biomass compared with the nodules on plants with $M$. loti. The average root length of the $R$. tropici seedlings was almost 2-fold longer than that of the M. loti seedlings (Table 1). The $\mathrm{N}$ concentration in the root tissues differed very little across treatments, but the ${ }^{15} \mathrm{~N}$ isotopes showed the source of root $\mathrm{N}$ differed. Roots of inoculated seedlings had depleted bulk $\delta^{15} \mathrm{~N}(-1.4 \%$ o $)$ when compared with atmospheric ${ }^{15} \mathrm{~N}(0 \%)$ and the roots of control seedlings $(+3.4 \%)$ (Table 1$)$. However, the whole plant $\delta^{15} \mathrm{~N}$ (calculated from the weighted total $\mathrm{N}$ contributions of shoots, roots and nodules to the whole plant) was not significantly different from $0 \%$ (Table 1 ). 
Table 1. Leaf, root and nodule traits of pot-cultured Leucaena leucocephala inoculated with different rhizobia strains (Mesorhizobium loti or Rhizobium tropici) and their respective controls (uninoculated plants). Numbers represent mean $\pm \operatorname{SE}(n=5$ at 60 days after inoculation (DAI) and $n=3$ at 140 DAI). Different letters indicate significant differences across harvest days within a rhizobial strain $(p<0.05$, Least significant differences (LSD) test, following ANOVA). Asterisks indicate the differences between atmospheric $\mathrm{N}_{2}(0 \%)$ and total-plant $\delta^{15} \mathrm{~N}$, analyzed by Student's $t$-test.

\begin{tabular}{|c|c|c|c|c|c|}
\hline \multirow[b]{3}{*}{ Trait } & \multicolumn{5}{|c|}{ Harvests } \\
\hline & \multicolumn{3}{|c|}{60 DAI } & \multicolumn{2}{|c|}{140 DAI } \\
\hline & M. loti & R. tropici & Control & M. loti & R. tropici \\
\hline Plant height $(\mathrm{cm})$ & $5.8 \pm 0.4^{b}$ & $5.4 \pm 0.4^{b}$ & $4.2 \pm 0.4^{b}$ & $12.2 \pm 1.4^{\mathrm{a}}$ & $14.8 \pm 0.6^{\mathrm{a}}$ \\
\hline Total plant biomass (g) & $0.5 \pm 0.1^{\mathrm{c}}$ & $0.5 \pm 0.1^{\mathrm{c}}$ & $0.3 \pm 0.1^{\mathrm{c}}$ & $3.2 \pm 0.5^{b}$ & $4.9 \pm 0.8^{a}$ \\
\hline Total plant $\delta^{15} \mathrm{~N}(\%)$ & $-0.9 \pm 0.3$ & $-0.4 \pm 0.2$ & $1.8 \pm 0.4 *$ & $-0.4 \pm 0.3$ & $-0.6 \pm 0.2$ \\
\hline Root-to-shoot ratio & $0.4 \pm 0.0^{\mathrm{b}}$ & $0.3 \pm 0.0^{b}$ & $0.6 \pm 0.1^{\mathrm{a}}$ & $0.6 \pm 0.0^{\mathrm{a}}$ & $0.7 \pm 0.0^{\mathrm{a}}$ \\
\hline Number of leaves (plant ${ }^{-1}$ ) & $7.0 \pm 1.4^{b c}$ & $8.4 \pm 1.2^{b}$ & $2.7 \pm 0.9^{c}$ & $24.7 \pm 1.8^{\mathrm{a}}$ & $22.0 \pm 3.8^{a}$ \\
\hline Leaf C (\%) & $42.1 \pm 0.3^{b c}$ & $42.9 \pm 1.7 \mathrm{abc}$ & $40.6 \pm 0.3^{c}$ & $43.6 \pm 0.2^{\mathrm{ab}}$ & $45.6 \pm 0.2^{a}$ \\
\hline Leaf N (\%) & $2.4 \pm 0.4^{b}$ & $2.1 \pm 0.3^{b}$ & $1.2 \pm 0.0^{\mathrm{c}}$ & $3.4 \pm 0.2^{\mathrm{a}}$ & $3.8 \pm 0.2^{\mathrm{a}}$ \\
\hline Leaf $\delta^{15} \mathrm{~N}(\%)$ & $-1.4 \pm 0.1$ & $-1.0 \pm 0.4$ & $-1.6 \pm 0.4$ & $-0.8 \pm 0.1$ & $-0.8 \pm 0.3$ \\
\hline Root length (cm) & $12.7 \pm 4.0^{b}$ & $21.0 \pm 2.0^{\mathrm{ab}}$ & $22.9 \pm 2.1^{\mathrm{a}}$ & $13.8 \pm 0.6^{\mathrm{ab}}$ & $23.5 \pm 5.2^{\mathrm{a}}$ \\
\hline Root C (\%) & $40.0 \pm 1.8^{b}$ & $41.1 \pm 0.0^{\mathrm{ab}}$ & $42.4 \pm 0.1 \mathrm{ab}$ & $41.8 \pm 0.3^{\mathrm{ab}}$ & $43.6 \pm 1.3^{\mathrm{a}}$ \\
\hline Root N (\%) & $1.7 \pm 0.2$ & $1.6 \pm 0.0$ & $1.7 \pm 0.0$ & $1.5 \pm 0.1$ & $1.6 \pm 0.2$ \\
\hline Root $\delta^{15} \mathrm{~N}(\%)$ & $-1.4 \pm 0.5^{b}$ & $-1.4 \pm 0.4^{b}$ & $3.4 \pm 0.1^{a}$ & $-1.8 \pm 0.4^{b}$ & $-1.8 \pm 0.2^{b}$ \\
\hline Nodules (plant ${ }^{-1}$ ) & $12.4 \pm 2.2^{\mathrm{a}}$ & $7.0 \pm 0.5^{b}$ & 0 & $13.7 \pm 0.5^{\mathrm{a}}$ & $13.3 \pm 0.6^{\mathrm{a}}$ \\
\hline Total nodule biomass (mg) & $11.4 \pm 0.9^{b}$ & $14.4 \pm 1.5^{b}$ & 0 & $78.3 \pm 12.4^{\mathrm{a}}$ & $70.1 \pm 8.8^{a}$ \\
\hline Nodule C (\%) & $41.8 \pm 0.1^{b}$ & $41.4 \pm 0.2^{b}$ & 0 & $44.7 \pm 1.3^{\mathrm{a}}$ & $43.1 \pm 0.8^{\mathrm{ab}}$ \\
\hline Nodule N (\%) & $4.3 \pm 0.0^{b}$ & $4.5 \pm 0^{b}$ & 0 & $4.4 \pm 0.1^{b}$ & $5.6 \pm 0.2^{\mathrm{a}}$ \\
\hline Nodules $\delta^{15} \mathrm{~N}(\%)$ & $4.9 \pm 0.2^{b}$ & $5.2 \pm 0.2^{\mathrm{ab}}$ & 0 & $7.4 \pm 0.8^{\mathrm{ab}}$ & $7.9 \pm 1.2^{\mathrm{a}}$ \\
\hline
\end{tabular}

At 140 DAI, stems started to lignify and all inoculated seedlings looked similar aboveground. The number of leaves, average plant height, and tissue $\mathrm{C}$ and $\mathrm{N}$ concentrations were not significantly different between plants associated with the two rhizobia strains. However, total plant biomass was significantly greater in $R$. tropici seedlings $(4.9 \pm 0.8 \mathrm{~g})$ compared with $M$. loti seedlings $(3.2 \pm 0.5 \mathrm{~g})$ (Table 1). Thus overall, $R$. tropici plants had fixed more $\mathrm{N}$ and $\mathrm{C}$ at this stage.

Nodule biomass was a much better predictor of total plant $\mathrm{N}$-fixed (Figure $2 \mathrm{~b}$ ) than the plant nodule count (Figure 2a). While the number of nodules per plant almost doubled in $R$. tropici seedlings at 140 DAI compared with 60 DAI, the nodule count did not increase in $M$. loti seedlings. Total nodule biomass significantly increased between 60 and 140 DAI and was very similar between strains (Table 1). Values of $\delta^{15} \mathrm{~N}$ remained constant for leaf and root tissues, but increased an additional 2.5\%o to 2.7\%o in the nodules between $60 \mathrm{DAI}$ and $140 \mathrm{DAI}$, respectively, for $M$. loti and R. tropici, with final $\delta^{15} \mathrm{~N}$ values in the nodules of $c .8 \%$ to $9 \%$ greater than the leaf or root ${ }^{15} \mathrm{~N}$ values (Table 1 ). 


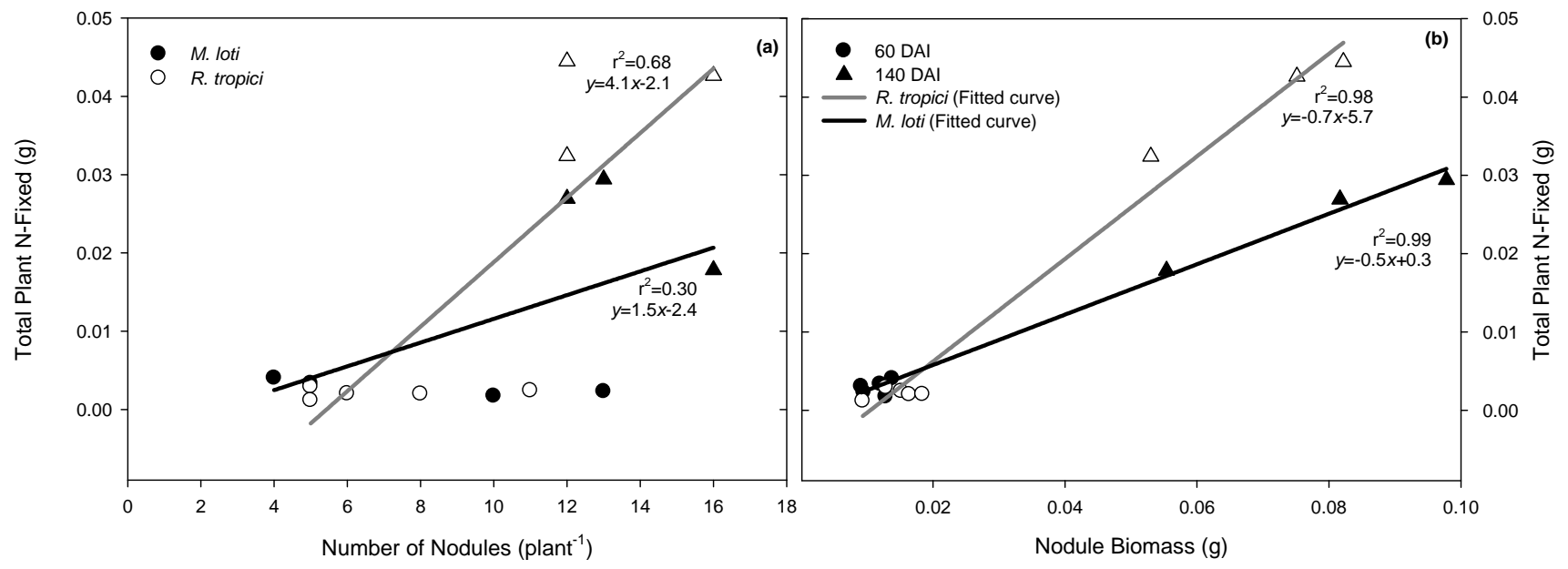

Figure 2. Total content of fixed nitrogen per plant as a function of plant nodule count (a) and nodule biomass (b) in Leucaena leucocephala seedlings inoculated with Mesorhizobium loti (filled bars) and Rhizobium tropici (open bars). Different symbols indicate single measurements at 60 DAI (circles) and 140 DAI (triangles). Fitted curves show the linear regression between parameters. Equations and the determination coefficient are included in each figure. DAI: days after inoculation.

\subsection{Drought-Induced Changes in Water Availability and Number of Nodules per Plant}

During a 15-day drought at 140 DAI (four and a half months after inoculation), the substrate water content (SWC) declined gradually from approximately $86.7 \%$ and $90.8 \%$ (Day 0 ) to $41.1 \%$ and $48.7 \%$ (Day 15) for M. loti and R. tropici seedlings, respectively (Table 2). All drought-affected seedlings showed signals of stress in that their leaves folded inward. However, in droughted seedlings, traits such as the number of leaves, the $\mathrm{C}$ and $\mathrm{N}$ concentration of the leaves and the root-to-shoot-ratio did not change (Table 2). In addition, irrigated plants did not change, except for a significant increase over the 15-day period, i.e., $155 \mathrm{DAI}$, in root biomass and the root-to-shoot ratio of $R$. tropici seedlings (Table 2). Thus, the growth of plants inoculated with $M$. loti was not affected by drought during this period. 
Table 2. Effect of a short drought on leaf, root and nodule traits of pot-cultured Leucaena leucocephala inoculated with different rhizobia strains (Mesorhizobium loti or Rhizobium tropici) and their respective controls (irrigated plants). Numbers represent mean $\pm \mathrm{SE}$ $(n=3)$. Harvests were conducted at the beginning of the short drought (day 0, 140 days after inoculation, DAI) and after 15 days at the end of the drought (day 15, $155 \mathrm{DAI}$ ). Different letters indicate significant differences across harvest days within a rhizobium strain ( $p<0.05$, Least significant differences (LSD) test, following ANOVA).

\begin{tabular}{|c|c|c|c|c|c|c|}
\hline & \multicolumn{6}{|c|}{ Days after the Short-Drought Pulse } \\
\hline & \multicolumn{2}{|c|}{0 (140 DAI) } & \multicolumn{2}{|c|}{15 (155 DAI) } & \multicolumn{2}{|c|}{ Irrigated Plants } \\
\hline & M. loti & R. tropici & M. loti & R. tropici & M. loti & R. tropici \\
\hline Soil water content $(\%)$ & $87.7 \pm 2.0^{\mathrm{a}}$ & $90.8 \pm 2.9^{\mathrm{a}}$ & $41.1 \pm 4.2^{b}$ & $48.7 \pm 2.4^{b}$ & $89.0 \pm 2.0^{\mathrm{a}}$ & $90.5 \pm 2.9^{a}$ \\
\hline Root-to-shoot ratio & $0.7 \pm 0.1^{b}$ & $0.8 \pm 0.0^{b}$ & $0.7 \pm 0.0^{b}$ & $0.7 \pm 0.0^{b}$ & $0.8 \pm 0.0^{b}$ & $0.9 \pm 0.1^{\mathrm{a}}$ \\
\hline $\begin{array}{l}\text { Number of leaves } \\
\left(\text { plant }^{-1}\right)\end{array}$ & $24.7 \pm 2.3$ & $22.0 \pm 3.8$ & $23.3 \pm 0.7$ & $25.3 \pm 3.3$ & $22.0 \pm 1.2$ & $24.0 \pm 0.0$ \\
\hline Leaf biomass (g) & $0.4 \pm 0.1^{\mathrm{ab}}$ & $0.6 \pm 0.1^{\mathrm{a}}$ & $0.4 \pm 0.0^{b}$ & $0.4 \pm 0.0^{b}$ & $0.3 \pm 0.1^{b}$ & $0.6 \pm 0.1^{\mathrm{a}}$ \\
\hline Leaf C (\%) & $43.6 \pm 0.1$ & $45.6 \pm 0.7$ & $45.3 \pm 2.3$ & $44.5 \pm 0.1$ & $44.9 \pm 1.2$ & $44.1 \pm 0.1$ \\
\hline Leaf N (\%) & $3.4 \pm 0.2^{\mathrm{ab}}$ & $3.8 \pm 0.2^{\mathrm{a}}$ & $3.3 \pm 0.2^{\mathrm{ab}}$ & $3.6 \pm 0.2^{\mathrm{ab}}$ & $3.1 \pm 0.4^{b}$ & $3.5 \pm 0.0^{\mathrm{ab}}$ \\
\hline Leaf $\delta^{15} \mathrm{~N}(\%)$ & $-0.8 \pm 0.1$ & $-0.8 \pm 0.3$ & $-0.9 \pm 0.2$ & $-1.1 \pm 0.4$ & $-1.4 \pm 0.2$ & $-0.9 \pm 0.3$ \\
\hline Leaf NSC (\%) & $4.9 \pm 0.3^{b}$ & $4.4 \pm 0.3^{b}$ & $8.6 \pm 0.7^{\mathrm{a}}$ & $5.2 \pm 0.3^{b}$ & -- & $4.1 \pm 0.3^{b}$ \\
\hline Root length (cm) & $13.8 \pm 0.6^{\mathrm{bc}}$ & $23.5 \pm 5.2^{a b}$ & $13.3 \pm 2.5^{c}$ & $23.6 \pm 5.1^{\mathrm{a}}$ & $12.9 \pm 0.9^{c}$ & $14.7 \pm 1.2^{\mathrm{abc}}$ \\
\hline Root biomass (g) & $0.5 \pm 0.1^{\mathrm{b}}$ & $0.7 \pm 0.1^{\mathrm{ab}}$ & $0.5 \pm 0.0^{b}$ & $0.6 \pm 0.1^{\mathrm{ab}}$ & $0.4 \pm 0.1^{\mathrm{b}}$ & $0.9 \pm 0.1^{\mathrm{a}}$ \\
\hline Root C (\%) & $41.8 \pm 0.3^{\mathrm{ab}}$ & $43.6 \pm 1.3^{\mathrm{a}}$ & $38.2 \pm 1.1^{b}$ & $41.5 \pm 0.8^{\mathrm{ab}}$ & $39.7 \pm 1.2^{\mathrm{b}}$ & $38.8 \pm 0.9^{\mathrm{ab}}$ \\
\hline Root N (\%) & $1.5 \pm 0.1$ & $1.6 \pm 0.2$ & $1.7 \pm 0.1$ & $1.7 \pm 0.1$ & $1.5 \pm 0.1$ & $1.4 \pm 0.1$ \\
\hline Root $\delta^{15} \mathrm{~N}(\%)$ & $-1.8 \pm 0.4$ & $-1.8 \pm 0.2$ & $-2.2 \pm 0.2$ & $-1.7 \pm 0.4$ & $-2.7 \pm 0.8$ & $-2.2 \pm 0.4$ \\
\hline Root NSC (\%) & $4.7 \pm 1.9^{b}$ & $6.4 \pm 0.2^{b}$ & $9.0 \pm 0.8^{a b}$ & $10.0 \pm 1.0^{\mathrm{ab}}$ & -- & $14.3 \pm 2.9^{a}$ \\
\hline $\begin{array}{l}\text { Number of nodules } \\
\left(\text { plant }^{-1}\right)\end{array}$ & $13.6 \pm 0.5^{b}$ & $13.3 \pm 0.6^{\mathrm{b}}$ & $6.7 \pm 0.3^{b}$ & $16.3 \pm 2.9^{a b}$ & $35.0 \pm 6.6^{\mathrm{a}}$ & $11.3 \pm 4.4^{b}$ \\
\hline Nodule biomass (mg) & $78.3 \pm 12.4^{\mathrm{ab}}$ & $70.1 \pm 8.8^{a b}$ & $60.1 \pm 17.1 \mathrm{ab}$ & $56.2 \pm 16.2^{\mathrm{ab}}$ & $41.3 \pm 3.0^{b}$ & $86.3 \pm 14.2^{\mathrm{a}}$ \\
\hline $\begin{array}{l}\text { Biomass per nodule } \\
\quad\left(\mathrm{mg} \text { nodule }^{-1}\right)\end{array}$ & $4.8 \pm 0.7^{\mathrm{ab}}$ & $5.3 \pm 1.0^{\mathrm{ab}}$ & $9.3 \pm 3.2^{\mathrm{a}}$ & $4.0 \pm 0.7^{a b}$ & $1.2 \pm 0.2^{b}$ & $11.4 \pm 5.0^{\mathrm{a}}$ \\
\hline Nodule C (\%) & $44.7 \pm 1.3^{\mathrm{a}}$ & $43.1 \pm 0.7^{\mathrm{ab}}$ & $40.7 \pm 0.4^{b}$ & $42.6 \pm 0.7^{\mathrm{ab}}$ & $42.7 \pm 0.3^{\mathrm{ab}}$ & $42.4 \pm 0.3^{\mathrm{ab}}$ \\
\hline Nodule N (\%) & $4.4 \pm 0.1^{\mathrm{c}}$ & $5.5 \pm 0.2^{\mathrm{a}}$ & $4.2 \pm 0.1^{\mathrm{c}}$ & $4.3 \pm 0.2^{c}$ & $5.0 \pm 0.1^{\mathrm{b}}$ & $4.4 \pm 0.0^{\mathrm{c}}$ \\
\hline Nodule $\delta^{15} \mathrm{~N}(\% \mathrm{o})$ & $7.4 \pm 0.8$ & $7.9 \pm 1.2$ & $7.9 \pm 0.5$ & $8.7 \pm 0.6$ & $8.0 \pm 0.9$ & $8.7 \pm 0.6$ \\
\hline Nodule NSC (\%) & $7.4 \pm 0.6^{\mathrm{ab}}$ & $2.4 \pm 0.1^{\mathrm{c}}$ & $10.1 \pm 1.8^{\mathrm{ab}}$ & $8.8 \pm 1.4^{\mathrm{ab}}$ & $9.3 \pm 0.7^{\mathrm{ab}}$ & $13.9 \pm 1.2^{\mathrm{a}}$ \\
\hline
\end{tabular}

R. tropici seedlings had more but lighter nodules when exposed to drought compared with both irrigated seedlings and $M$. loti seedlings under drought (Table 2). The NSC increased in the roots and nodules of seedlings of both strains under drought or irrigation, with the largest increases in the nodules of $R$. tropici plants. In contrast, the NSC also increased in the leaves of $M$. loti plants affected by drought (Table 2).

Roots were more depleted in ${ }^{15} \mathrm{~N}$ than leaves, compared with the atmospheric ${ }^{15} \mathrm{~N}$ concentration (i.e., $\delta^{15} \mathrm{~N}<0 \%$ ) (Table 2). Nodule $\delta^{15} \mathrm{~N}$ values increased $(>0.5 \%$ to $0.8 \%$ ) and their $\mathrm{N}$ concentration decreased for both rhizobia strains after 15 days of drought (Table 2).

Amino acid concentrations in nodules decreased slightly during the drought treatment and compared with the irrigated seedlings (Figure 3a), especially in M. loti. Glutamic acid (Figure 3b) and 
asparagine (Figure $3 \mathrm{c}$ ) represented $\sim 63 \%$ and $\sim 66 \%$ of the total amino acid (by mass) analyzed in the nodules of $R$. tropici and $M$. loti, respectively. Drought affected mostly asparagine in the nodules of $M$. loti and $R$. tropici, causing reductions of $44 \%$ (Figure $3 \mathrm{c}$ ). In contrast, proline significantly increased after 15 days of drought (Figure 3d) at a similar rate from $10.3 \pm 0.8$ to $58.6 \pm 3.7 \mathrm{nmol} \mathrm{g}^{-1}$ in the nodules of $M$. loti seedlings, and from $2.8 \pm 0.7$ to $48.6 \pm 5.8 \mathrm{nmol} \mathrm{g}^{-1}$ in the nodules of R. tropici seedlings.
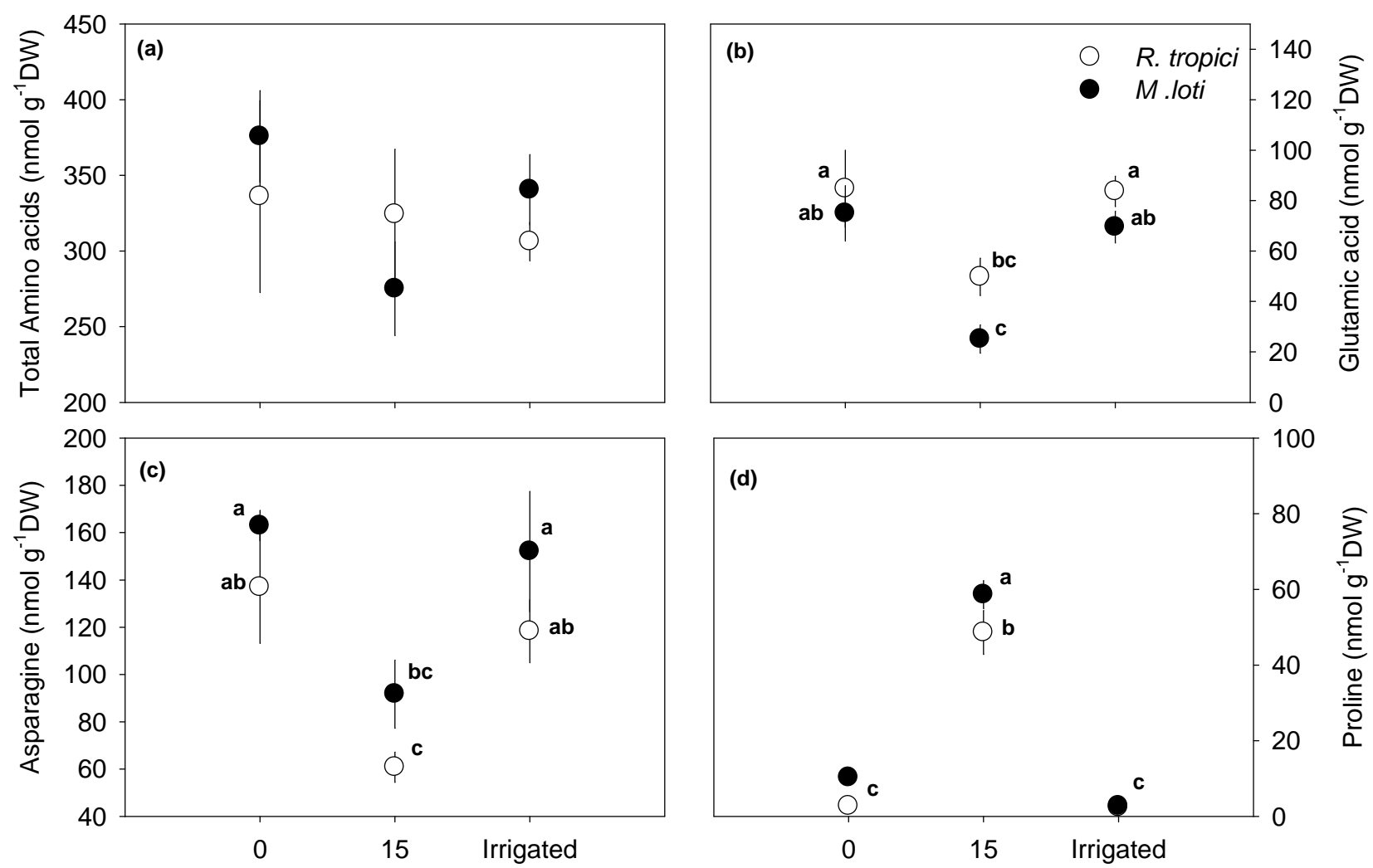

Time (Days after the drought pulse)

Figure 3. Average total amino acids (a); glutamic acid (b); asparagine (c) and proline (d) in the nodules of Leucaena leucocephala inoculated with Mesorhizobium loti (filled symbols) and Rhizobium tropici (open symbols) under a short drought or irrigation. Values represent means \pm SE $(n=3)$. Different upper-case letters denote significant differences between strains, lower-case letters across harvest days $(p<0.05$, Least significant differences (LSD) test, following ANOVA).

\section{Discussion}

The choice of $\mathrm{N}$-fixing trees for forest restoration and agroforestry in drought-prone systems is usually based on plant growth traits (e.g., survival rate, fast vs. slow growth, $\mathrm{C}$ and $\mathrm{N}$ tissue concentrations) $[29,44]$. The use of such traits has led to variable growth responses to heterogeneous environmental conditions, differences in propagation success in tree nurseries, and the initial performance of trees $[45,46]$. However, the contribution of the rhizobial strain associated with various plants has received less attention, especially with respect to plant response to drought. 
Our study demonstrates that different rhizobia strains in the Leucaena-rhizobium symbiosis had substantial impacts on growth and development, both during early seedling stages and during drought.

\subsection{Effects of Rhizobium on Nodulation, Seedling Growth, and Total Plant N}

A common understanding in legume-rhizobia symbiosis is that larger plants can support more nodules and can establish themselves earlier [8], which in turn translates into faster growth, higher biomass, and more $\mathrm{N}$ in plant tissues [47]. However, this was not the case in our experiment; the number of nodules did not increase over time in $M$. loti seedlings, a phenomenon that has also been observed in other studies on L. leucocephala inoculated with M. loti (Strains: MAFF 303099 and R7A) $[48,49]$. Such a regulation of nodule formation was attributed to the presence of secretion systems, which are large protein complexes that are exported across bacterial membranes and cell walls [50]. The regulation of the total number of nodules in $M$. loti seedlings was associated with negative effects on biomass and $\mathrm{N}$ accumulation in Leucaena.

In our study, Leucaena was an obligate $\mathrm{N}$-fixer at early growth stages, and seedlings regulated the $\mathrm{N}$ content via changes in their whole plant biomass [51], as indicated by the fact that $\mathrm{N}$ was fixed at the same rate per unit of biomass independent of growth phase (Figure 2). Seedlings inoculated with $R$. tropici had higher biomass accumulation and $\mathrm{N}$-fixation. The hypothesis of our study was confirmed, as N-fixation and biomass accumulation differed between inoculated strains, a result also observed for Acacia sp. inoculated with different rhizobia strains (i.e., phylotypes) [52]. Furthermore, the amount of $\mathrm{N}$-fixed during a given period of time was strongly related to nodule biomass, but not to nodule count (Figure 2b). Similar results have been observed in Medicago truncatula, where higher $\mathrm{N}$-fixation rates (measured as apparent nitrogenase activity) were observed in association with the strain that yielded higher nodule biomass [12].

Belowground tissues contributed to $33 \%-35 \%$ of the seedling total $\mathrm{N}$, i.e., three-fold higher than that reported for pasture legumes [53]. Belowground tissues therefore contain a substantial proportion of total $\mathrm{N}$ fixed by plants, as has been observed in field experiments, albeit to a lesser degree (7\%-10\%) [54]. The observed differences are probably related to differences in plant type (pasture legume vs. woody legume) and/or to the type of manipulation (field experiment vs. greenhouse experiment). However, when $\mathrm{N}$ content and tissue $\delta^{15} \mathrm{~N}$ are integrated over the whole plant, applying a mass balance approach, we did not observe isotope discrimination against ${ }^{15} \mathrm{~N}$ compared with atmospheric $\mathrm{N}_{2}$ (i.e., the $\delta^{15} \mathrm{~N}$ for the whole plant was $\sim 0 \%$ ) [18]. We found that the $\delta^{15} \mathrm{~N}$ values of the nodules increased with time and were enriched compared with atmospheric $\mathrm{N}_{2}$, while other plant tissues were depleted in $\delta^{15} \mathrm{~N}$ by comparison. This has also been observed in other studies of legume shrubs and trees inoculated with Rhizobium sp. [16]. The reason for such large enrichment of ${ }^{15} \mathrm{~N}$ in nodules is still debated [18]. One hypothesis is that deamination reactions produce ${ }^{15} \mathrm{~N}$-depleted ammonia $\left(\mathrm{NH}_{3}\right)$, which is exported out of the nodules, leaving residual $\mathrm{N}$ that is enriched in ${ }^{15} \mathrm{~N}$ [53], causing nodule $\delta^{15} \mathrm{~N}$ increases. The subsequent assimilation of the exported $\mathrm{NH}_{3}$ into growing plant tissues would thus explain their depletion in ${ }^{15} \mathrm{~N}$ [54]. We observed concurrent changes in $\mathrm{N}$ concentration in aging leaves associated with a ${ }^{15} \mathrm{~N}$ enrichment of $c .0 .6 \%$, so that discrimination processes other than $\mathrm{N}$-fixation must have been operating [18]. Methodological approaches using ${ }^{15} \mathrm{~N}$ to partition total $\mathrm{N}$ into symbiotically fixed vs. soil-uptake $\mathrm{N}$ in leaf tissues need to consider this post-fixation fractionation in their calculations. 


\subsection{Leucaena Symbiosis during Drought: Root Length and N-Fixation}

Leucaena is known as a drought-tolerant species with a deep rooting system [56]. Under short-term drought stress, Leucaena seedlings associated with $R$. tropici had greater root length than $M$. loti seedlings. This is interpreted as a survival strategy during soil water depletion [5] by allowing plants to explore a greater soil volume.

Drought caused plant growth to cease and resulted in slight reductions of plant $\mathrm{N}$ in $R$. tropici seedlings, which might indicate greater $\mathrm{N}$ use without resupply from $\mathrm{N}$-fixation. On the other hand, $M$. loti seedlings stopped growing before the short drought started. This might be related to the regulation of the number of nodules discussed earlier, rather than regulation of $\mathrm{N}$-fixation due to drought. Regulation of the symbiotic N-fixation during drought is complex and yet not fully understood [55]. Other pot experiments with short drought spells (7 days) have shown a reduction of $\mathrm{N}$-fixation via impairment of bacteriod $\mathrm{C}$ metabolism [56] and/or accumulation of amino acids (i.e., $\mathrm{N}$-feedback) [22]. Apart from a strong accumulation of proline, a common drought stress response, the total amino acid concentration in the nodules did not increase after 15 days and hence cannot be explained by $\mathrm{N}$-feedback mechanisms in our experiment. However, the accumulation of NSC in nodules might indicate that levels of sucrose synthase, a key enzyme in the hydrolysis of sucrose to hexoses in nodules, was reduced by drought [57], leading to a limitation of respiratory substrate for bacteriods [58]. The respiratory substrate for bacteriods is malate, derived from the catabolism of hexoses to oxaloacetate and ultimately, reduced to malate, due to the enzyme malate dehydrogenase [59]. Such a mechanism has been observed in pea and soybean (Glycine max), but not in Medicago truncatula [55] and may lend support to our hypothesis that drought down-regulated N-fixation due to reduced $\mathrm{C}$ availability to fuel bacteriod respiration in $R$. tropici seedlings.

In a restoration effort of degraded agricultural land in Mexico, the establishment rate and drought survival were greater for legume seedlings that grew for two months under controlled conditions before planting [60]. Applying our results to field conditions, Leucaena seedlings grown with $R$. tropici until lignification occurs are likely to gain more biomass and increase $\mathrm{N}$ tissue content compared with those grown with $M$. loti. The R. tropici symbiosis also allowed increases in root length, which might enable the plant to better respond to drought conditions by exploring distant soil water pools. However, a co-limitation of phosphorus (P) should always be considered in tropical ecosystems, where low availability of $\mathrm{P}$ may prevent $\mathrm{N}$ fixers from having a significant advantage [61]. While there has been a clear emphasis on how drought affects leguminous trees and their performance in reforestation efforts or agroforestry, there are major knowledge gaps in how other abiotic stressors affect the rhizobia-host symbiosis.

\section{Concluding Remarks and Implications}

Under the controlled conditions of our manipulation, Leucaena was an obligate N-fixer and $\mathrm{N}$-fixation occurred during the whole seedling growth phase. However, when Leucaena was inoculated with $R$. tropici, it fixed more $\mathrm{N}$ and gained more biomass than seedlings associated with M. loti. Though both associations ceased fixing $\mathrm{N}$ during drought, $R$. tropici seedlings had on average longer roots, and their nodules accumulated more proline, suggesting that seedlings inoculated with $R$. tropici 
are likely better able to survive drought. For better results in forest restoration and agroforestry applications, we recommend the growth of Leucaena trees in association with $R$. tropici under controlled conditions until lignification occurs, before transplanting the seedlings to the field.

\section{Acknowledgments}

We thank Agnes Fastnacht and Savoyane Lambert for their help with greenhouse work, Ines Hilke and Birgit Fröhlich for the $\mathrm{CN}$ analysis, Heike Geilmann for isotopic measurements, as well as Iris Kuhlmann, Anett Enke and Diamarys Dominguez for NSC measurements. We also thank Michael Reichelt from the MPI for Chemical Ecology for amino acid measurements. Gabriela Pereyra conducted this work as a member of the International Max Planck Research School for Biogeochemical Cycles.

\section{Author Contributions}

Conceived and designed the experiments: Gabriela Pereyra, Susan Trumbore, Henrik Hartmann and Waldemar Ziegler; performed the experiments: Gabriela Pereyra and Waldemar Ziegler; wrote the paper together: Gabriela Pereyra, Henrik Hartmann, Beate Michalzik and Susan Trumbore.

\section{Conflicts of Interest}

The authors declare no conflicts of interest.

\section{References}

1. Thrall, P.H.; Laine, A.-L.; Broadhurst, L.M.; Bagnall, D.J.; Brockwell, J. Symbiotic Effectiveness of Rhizobial Mutualists Varies in Interactions with Native Australian Legume Genera. PLoS ONE 2011, 6, e23545.

2. Spehn, E.M.; Scherer-Lorenzen, M.; Schmid, B.; Hector, A.; Caldeira, M.C.; Dimitrakopoulos, P.G.; Finn, J.A.; Jumpponen, A.; O’Donnovan, G.; Pereira, J.S.; et al. The role of legumes as a component of biodiversity in a cross-European study of grassland biomass nitrogen. Oikos 2002 , 98, 205-218.

3. Miles, L.; Newton, A.C.; DeFries, R.S.; Ravilious, C.; May, I.; Blyth, S.; Kapos, V.; Gordon, J.E. A global overview of the conservation status of tropical dry forests. J. Biogeogr. 2006, 33, 491-505.

4. IPCC. Climate Change 2014: Synthesis Report. Contribution of Working Groups I, II and III to the Fifth Assessment Report of the Intergovernmental Panel on Climate Change; IPCC: Geneva, Switzerland, 2014; p. 151.

5. Zahran, H.H. Rhizobium-legume symbiosis and nitrogen fixation under severe conditions and in an arid climate. Microbiol. Mol. Biol. Rev. MMBR 1999, 63, 968-989.

6. Miller, S.H.; Elliot, R.M.; Sullivan, J.T.; Ronson, C.W. Host-specific regulation of symbiotic nitrogen fixation in Rhizobium leguminosarum biovar trifolii. Microbiology 2007, 153, 3184-3195.

7. Wang, D.; Yang, S.; Tang, F.; Zhu, H. Symbiosis specificity in the legume-rhizobial mutualism. Cell. Microbiol. 2012, 14, 334-342. 
8. Giller, K.E.; Bala, A. Symbiotic specificity of tropical tree rhizobia for host legumes. New Phytol. 2000, 149, 495-507.

9. Perret, X.; Staehelin, C.; Broughton, W.J. Molecular basis of symbiotic promiscuity. Microbiol. Mol. Biol. Rev. 2000, 64, 180-201.

10. Tharall, P.H.; Burdon, J.J.; Woods, M.J. Variations in effectiveness of symbiotic associations between native rhizobia and temperate Australian legumes: Interactions within and between genera. J. Appl. Ecol. 2000, 37, 52-65.

11. Sanginga, N.; Mulongoy, K.; Ayanaba, A. Efectivity of indigenous rhizobia for nodulation and aerly nitrogen fixation with Leucaena leucocephala grown in Nigerian soils. Soil. Biol. Biochem. 1989, 21, 231-235.

12. Larrainzar, E.; Gil-Quintana, E.; Seminario, A.; Arrese-Igor, C.; Gonzalez, E.M. Nodule carbohydrate catabolims is enhanced in the Medicago truncatula A17-Sinorhizobium medicae WSM419 symbiosis. Front. Microbiol. 2014, 5, 447, doi:10.3389/fmicb.2014.00447.

13. Tricot, F.; Crozat, Y.; Pellerin, S. Root growth and nodule establisment on pea (Pisum sativum L.). J. Exp. Bot. 1997, 48, 1938-1941.

14. Voisin, A.S.; Salon, C.; Jeudy, C.; Warembourg, F.R. Root and nodule growth in Pisum sativum L. in relation to photosynthesis: Analysis using ${ }^{13} \mathrm{C}$-labelling. Ann. Bot. 2003, 92, 557-563.

15. Zahran, H.H. Rhizobia from wild legumes: Diversity, taxonomy, ecology, nitrogen fixation and biotechnology. J. Biotechnol. 2001, 91, 143-153.

16. Boddey, R.M.; Peoples, M.B.; Palmer, B.; Dart, P.J. Use of the ${ }^{15} \mathrm{~N}$ natural abundance technique to quantify biological nitrogen fixation by woody perennial. Nutr. Cycl. Agroecosystems 2000, 57, 235-270.

17. Wanek, W.; Arndt, S.K. Difference in $\delta^{15} \mathrm{~N}$ signatures between nodulated roots and shoots of soyben is indicative of the contribution of symbiotic $\mathrm{N}_{2}$ fixation to plant N. J. Exp. Bot. 2002, 53, 1109-1118.

18. Unkovich, M. Isotope discrimination provides new insight into biological nitrogen fixation. New Phytol. 2013, 198, 643-646.

19. Unkovich, M.; Pate, J.S.; Lefroy, E.C.; Arthur, D.J. Nitrogen isotope fractionation in the fodder tree legume tagasaste (Chamaecytisus proliferus) and assessment of $\mathrm{N}_{2}$ fixation inputs in deep sandy soils of Western Australia. Aust. J. Plant Physiol. 2000, 45, 119-132.

20. Robinson, D.; Handley, L.L.; Scrimgeour, C.M.; Gordon, D.C.; Forster, B.P.; Ellis, R.P. Using stable isotope natural abundances $\left(\delta^{15} \mathrm{~N}\right.$ and $\left.\delta^{13} \mathrm{C}\right)$ to integrate the stress responses of wild barley (Hordeum spontaneus C. Koch.) genotypes. J. Exp. Bot. 2000, 51, 41-50.

21. Kohl, D.H.; Bryan, B.A.; Shearer, G. Relationship between $\mathrm{N}_{2}$-fixing efficiency and natural ${ }^{15} \mathrm{~N}$ enrichment of soybena nodules. Plant Physiol. 1983, 73, 514-516.

22. Gil-Quintana, E.; Larrainzar, E.; Arrese-Igor, C.; González, E.M. Is N-feedback involved in the inhibition of nitrogen fixation in drought-stressed Medicago truncatula? J. Exp. Bot. 2013, 64, 281-292.

23. Muller, B.; Pantin, F.; Genard, M.; Turc, O.; Freixes, S.; Piques, M.; Gibon, Y. Water deficits uncouple growth from photosynthesis, increase $\mathrm{C}$ content, and modify the relationships between $\mathrm{C}$ and growth in sink organs. J. Exp. Bot. 2011, 62, 1715-1729. 
24. Mengel, K. Symbiotic dinitrogen fixation-Its dependance on plant nutrition and its ecophysiological impact. J. Plant Nutr. Soil Sci. 1994, 157, 233-241.

25. Neo, H.H.; Layzell, D.B. Phloem glutamine and the regulation of $\mathrm{O}_{2}$ diffusion in legume nodules. Plant Physiol. 1997, 113, 259-267.

26. Sulieman, S.; Fischinger, S.A.; Gresshoff, P.M.; Schulze, J. Asparagine as a major factor in the $\mathrm{N}$-feedback regulation of $\mathrm{N}_{2}$ fixation in Medicago truncatula. Physiol. Plant. 2010, 140, 21-31.

27. Orwa, C.; Mutua, A.; Kindt, R.; Jamnadass, R.; Anthony, S. Agroforestree Database: A Tree Reference and Selection Guide; World Agroforestry Center: Nairobi, Kenya, 2009.

28. Shelton, H.M. The Leucaena genus: New opportunities for agriculture. In Proccedings of the Leucaena-Adaptation, Quality and Farming Systems, Hanoi, Vietnam, 9-14 February 1998; Shelton, H.M., Gutteridge, R.C., Mullen, B.F., Eds.; ACIAR: Brisbane, Australia, 1998; pp. $15-25$.

29. Casanova-Lugo, F.; Petit-Aldana, J.; Solorio-Sánchez, F.J.; Parsons, D.; Ramírez-Avilés, L. Forage yield and quality of Leucaena leucocephala and Guazuma ulmifolia in mixed and pure fodder banks systems in Yucatan, Mexico. Agrofor. Syst. 2014, 88, 29-39.

30. Shelton, M.; Scott, D. Production, economic and environmental benefi ts of leucaena pastures. Trop. Grassl. 2007, 41, 174-190.

31. Oono, R.; Denison, F.R. Comparing symbiotic efficiency between swollen versus nonswollen rhizobial bacteriods. Plant Physiol. 2010, 154, 1541-1548.

32. Jarvis, B.D.W.; VanBerkum, P.; Chen, W.X.; Nour, S.M.; Fernandez, M.P.; CleyetMarel, J.C.; Gillis, M. Transfer of Rhizobium loti, Rhizobium huakuii, Rhizobium ciceri, Rhizobium mediterraneum, and Rhizobium tianshanense to Mesorhizobium gen. nov. Int. J. Syst. Bacteriol. 1997, 47, 895-898.

33. Hansen, A.P. Symbiotic $N_{2}$ Fixation of Crop Legumes: Achievements and Perspectives; Margraf Verlag: Weikersheim, Germany, 1994; p. 248.

34. Romero-Martinez, E.; Segovia, L.; Martins Mercante, F.; Franco, A.A.; Graham, P.; Pardo, M.A. Rhizobium tropici, a Novel Species Nodulating Phaseolus vulgaris L. Beans and Leucaena sp. Trees. Int. J. Syst. Bacteriol. 1991, 41, 417-426.

35. Forestier, S.; Alvarado, G.; Badjel S.B.; Lesueur, D. Effect of Rhizobium inoculation methodologies on nodulation and growth of Leucaena leucocephala. World J. Microbiol. Biotechnol. 2001, 17, 359-362.

36. Mrema, A.F.; Granhall, U.; Sennerby-Forsse, L. Plant growth, leaf water potential, nitrogenase activity and nodule anatomy in Leucaena leucocephala as affected by water stress and nitrogen availability. Trees-Struct. Funct. 1997, 12, 42-48.

37. Thies, J.E.; Singleton, P.W.; Bohlool, B.B. Influence of the size of indigenous rhizobial populations on establishment and symbiotic performance of introduced rhizobia on field-grown legumes. Appl. Environ. Microbiol. 1991, 57, 19-28.

38. Kadiata, B.D.; Mulongoy, K.; Isirimah, N.O. Time course of biological nitrogen fixation, nitrogen absorption and biomass accumulation in three woody legumes. Biol. Agric. Hortic. 1996, 13, 253-266. 
39. Unkovich, M.; Herridge, D.; Peoples, M.; Cadisch, G.; Boddey, B.; Giller, K.E.; Alves, B.; Chalk, P. Measuring Plant-Associated Nitrogen Fixation in Agricultural Systems; ACIAR: Canberra, Australia, 2008; Volume 136.

40. Raessler, M.; Wissuwa, B.; Breul, A.; Unger, W.; Grimm, T. Chromatographic analysis of major non-structural carbohydrates in several wood species-An analytical approach for higher accuracy of data. Anal. Methods 2010, 2, 532.

41. Docimo, T.; Reichelt, M.; Schneider, B.; Kai, M.; Kunert, G.; Gershenzon, J.; D’Auria, J.C. The first step in the biosynthesis of cocaine in Erythroxylum coca: The characterization of arginine and ornithine decarboxylases. Plant Mol. Biol. 2012, 78, 599-615.

42. Team, R.C. R: A Language and Environment for Statistical Computing; R Foundation for Statistical Computing: Vienna, Austria, 2014.

43. De Mendiburu, F. Agricolae: Statistical Procedures for Agricultural Research. R Package Version 1.1-8; R Foundation for Statistical Computing: Vienna, Austria, 2014.

44. Ceccon, E.; Sánchez, I.; Powers, J.S. Biological potential of four indigenous tree species from seasonally dry tropical forest for soil restoration. Agrofor. Syst. 2015, 89, 455-467.

45. Craven, D.; Dent, D.; Braden, D.; Ashton, M.S.; Berlyn, G.P.; Hall, J.S. Seasonal variability of photosynthetic characteristics influences growth of eight tropical tree species at two sites with contrasting precipitation in Panama. For. Ecol. Manag. 2011, 261, 1643-1653.

46. Hall, J.S.; Ashton, M.S.; Garen, E.J.; Jose, S. The ecology and ecosystem services of native trees: Implications for reforestation and land restoration in Mesoamerica. For. Ecol. Manag. 2011, 261, 1553-1557.

47. Kiers, E.T.; Ratcliff, W.C.; Denison, F.R. Single-strain inoculation may create spurious correlations between legume fitness and rhizobial fitness. New Phytol. 2013, 198, 4-6.

48. Hubber, A.; Vergunst, A.C.; Sullivan, J.T.; Hooykaas, P.J.J.; Ronson, C.W. Symbiotic phenotypes and translocated effector proteins of the Mesorhizobium loti strain $\mathrm{R}_{7} \mathrm{~A}$ VirB/D4 type IV secretion system. Mol. Microbiol. 2004, 54, 561-574.

49. Hubber, A.M.; Sullivan, J.T.; Ronson, C.W. Symbiosis-induced cascade regulation of the Mesorhizobium loti $\mathrm{R}_{7} \mathrm{~A}$ VirB/D4 type IV secretion system. Mol. Plant Microbe Interact. 2007, 20, 255-261.

50. Nelson, M.S.; Sadowsky, M.J. Secretion systems and signal exchange between nitrogen-fixing rhizobia and legumes. Front. Plant Sci. 2015, 6, 491, doi:10.3389/fpls.2015.00491.

51. Menge, L.D.N.; Levin, S.A.; Hedin, L.O. Facultative versus obligate nitrogen fixation strategies ans their ecosystem consequences. Am. Nat. 2009, 174, 465-477.

52. Bever, J.D.; Broadhurst, L.M.; Tharall, P.H. Microbial phylotype composition and diversity predicts plant productivity and plant-soil feedbacks. Ecol. Lett. 2013, 16, 167-174.

53. Kohl, D.H.; Reynolds, S.P.H.; Shearer, G. Distibution of ${ }^{15} \mathrm{~N}$ within Pea, Lupin and Soybean Nodules. Plant Physiol. 1989, 90, 420-426.

54. Ohyama, T.; Kumazawa, K. Nitrogen assimilation in soybena nodules. II ${ }^{15} \mathrm{~N}_{2}$ assimilation in bacteriods and cytosol fractions of soybean nodules. Jpn. Soc. Soil Sci. Plant Nutr. 1980, 26, 205-213. 
55. Larrainzar, E.; Wienkoop, S.; Scherling, C.; Kempa, S.; Ladrera, R.; Arrese-Igor, C.; Weckwerth, W.; Gonzalez, E.M. Carbon metabolism and bacteroid functioning are involved in the regulation of nitrogen fixation in Medicago truncatula under drought and recovery. Mol. Plant-Microbe Interact. MPMI 2009, 22, 1565-1576.

56. Nasr Esfahani, M.; Sulieman, S.; Schulze, J.; Yamaguchi-Shinozaki, K.; Shinozaki, K.; Tran, L.-S.P. Mechanisms of physiological adjustment of $\mathrm{N}_{2}$ fixation in Cicer arietinum L. (chickpea) during early stages of water deficit: Single or multi-factor controls. Plant J. 2014, 79, 964-980.

57. Gonzalez, E.M.; Aparicio-Trejo, P.; Gordon, A.J.; Minchin, F.R.; Royuela, M.; Arrese-Igor, C. Water-deficit effects on carbon and nitrogen metabolism of pea nodules. J. Exp. Bot. 1998, 49, 1705-1714.

58. Ladrera, R.; Marino, D.; Larrainzar, E.; Gonzalez, E.M.; Arrese-Igor, C. Reduced carbon availability to bacteriods and elevated ureides in nodules, but not in shoots, are involved in the nitrogen fixation response to early drought in soybean. Plant Physiol. 2007, 144, 1495-1507.

59. Vance, C.P.; Gantt, J.S. Primary assimilation of nitrogen in alfalfa nodules-molecular features of the enzymes involved. Plant Sci. 1992, 101, 51-64.

60. Martínez-Garza, C.; Tobon, W.; Campo, J.; Howe, H.F. Drought mortality of tree seedlings in an eroded tropical pasture. Land Degrad. Dev. 2013, 24, 287-295.

61. Davinson, E.A.; Reis de Carvalho, C.J.; Vieira, I.C.G.; Ricardo, D.F.O.; Mountinho, P.; Yoko Ishida, F.; Primo Dos Santos, M.T.; Guerrero, J.B.; Kalif, K.; Saba, R.T. Nitrogen and phosporus limitation of biomass growth in a tropical secondary forest. Ecol. Appl. 2004, 14, $150-163$.

(C) 2015 by the authors; licensee MDPI, Basel, Switzerland. This article is an open access article distributed under the terms and conditions of the Creative Commons Attribution license (http://creativecommons.org/licenses/by/4.0/). 